Article

\title{
Improve Pasture or Feed Grain? Greenhouse Gas Emissions, Profitability, and Resource Use for Nelore Beef Cattle in Brazil's Cerrado and Amazon Biomes
}

\author{
Luana Molossi $^{1}{ }^{(\mathbb{C}}$, Aaron Kinyu Hoshide ${ }^{2}{ }^{(}$, Lorena Machado Pedrosa ${ }^{1}$, \\ André Soares de Oliveira ${ }^{3}$ (D) and Daniel Carneiro de Abreu ${ }^{1, *(\mathbb{D})}$ \\ 1 AgriSciences, Universidade Federal de Mato Grosso, Sinop, MT 78555-267, Brazil; \\ luana_molossi@hotmail.com (L.M.); pedrosa@agronoma.eng.br (L.M.P.) \\ 2 Faculty Associate, School of Economics, The University of Maine, Orono, ME 04469, USA; \\ aaron.hoshide@maine.edu \\ 3 Dairy Cattle Research Lab, Universidade Federal de Mato Grosso, Sinop, MT 78555-267, Brazil; \\ andresoli@uol.com.br \\ * Correspondence: abreu@ufmt.br; Tel.: +55-66-3515-8574
}

Received: 23 May 2020; Accepted: 29 July 2020; Published: 10 August 2020

check for updates

Simple Summary: Deforested areas in Brazil's Amazon and Cerrado savannah have historically transitioned to pasture for grazing tropical beef cattle. Brazil's projected growth in beef exports emphasizes the importance of sustainably intensifying Brazil's cattle industry on existing agricultural land without increasing deforestation nor accelerating land conversion. We adapted a widely used simulation model for cattle, pasture, and crops to closely match two cooperating beef farms, one in the Cerrado and one in the Amazon. We then simulated the adoption of pasture fertilization, pasture re-seeding, and pasture-based grain supplementation of cattle by a model beef farm. These three sustainable agricultural intensification strategies were compared to extensive cattle grazing, the status quo in Brazil. Beef productivity and economic returns were greater for grain supplementation, followed by pasture fertilization and pasture re-seeding. Grain supplementation had the lowest greenhouse gas emissions, with less energy and nitrogen use compared to extensive grazing, as measured as a "footprint" for every unit of beef body weight produced. Pasture re-seeding and fertilization had lower greenhouse gas footprints compared to extensive; however, water and energy use and nitrogen losses were greater. Grain supplementation used more human edible livestock feed than other strategies, so pasture intensification could increase future human food availability.

\begin{abstract}
Economic development, international food and feed demand, and government policies have converted Brazil's natural ecosystems into agricultural land. The Integrated Farm System Model (IFSM) was evaluated using production, economic, and weather data collected on two cooperating farms in the Legal Amazon and Cerrado biomes in the Midwest state of Mato Grosso, Brazil. Three sustainable agricultural intensification strategies, namely grain supplementation, pasture re-seeding, and pasture fertilization were simulated in IFSM with double the beef cattle stocking density compared to extensive grazing. Livestock dry matter consumption simulated in IFSM was similar for pasture grazing estimates and actual feed consumed by beef cattle on the two collaborating farms. Grain supplementation best balanced beef production and profitability with lower carbon footprint compared to extensive grazing, followed by pasture fertilization and pasture re-seeding. However, pasture re-seeding and fertilization had greater use of water and energy and more nitrogen losses. Human edible livestock feed use was greatest for grain supplementation compared to other modeled systems. While grain supplementation appears more favorable economically and environmentally, greater use of human edible livestock feed may compete with future human food needs. Pasture intensification had greater human edible feed conversion efficiency, but its greater natural resource use may be challenging.
\end{abstract}


Keywords: agriculture; Amazon; beef cattle; Cerrado; environmental impacts; sustainable agricultural intensification; carbon footprint

\section{Introduction}

Global population's projected peak during the second half of this century is about 9.4 billion between 2060 to 2080 [1]. Food production needs to grow in a similar way to meet demand. Brazil is expected to be an important contributor to meeting global food requirements, accounting for $70 \%$ of projected production in 2050 [2]. The beef cattle industry is an important sector for the Brazilian economy, supplying animal protein for both national and international markets [3]. With a cattle herd of 221.81 million head, Brazil is the largest producer and second largest exporter of beef ( 2 billion metric tons of carcass equivalent), having slaughtered more than 39.2 million cattle in 2017 [4]. The Cerrado (i.e., tropical savannah) biome is estimated to have more than 30\% of Brazil's cattle herd and is responsible for $55 \%$ of slaughtered beef in the country [5,6]. The Amazon biome makes up almost half of Brazil's land area and supports $38 \%$ of Brazil's cattle herd $[7,8]$.

Economic development, international market demand for food and livestock feed, and government policies have led to the transformation of natural ecosystems into agricultural land in Brazil [9]. Agricultural expansion in Brazil's Amazon and Cerrado biomes involving extensive grazing of beef cattle has generated effects that are not only local but global, such as increased emissions of carbon dioxide $\left(\mathrm{CO}_{2}\right)$, due to land use conversion of forest to agricultural areas $[10,11]$, and cattle enteric fermentation (methane or $\mathrm{CH}_{4}$ ), as well as urine and feces decomposition, which releases nitrous oxide $\left(\mathrm{N}_{2} \mathrm{O}\right)[12]$.

In Brazil, the agricultural sector accounts for 35\% of all 2010 emissions, with more than half $(56 \%)$ estimated to come from cattle $\left(\mathrm{CH}_{4}\right)$ and an additional $18 \%$ of direct and indirect emissions of nitrous oxide $\left(\mathrm{N}_{2} \mathrm{O}\right)$ from animal excreta deposited on pasture mainly by cattle grazing on extensive pastures $[13,14]$. The recovery of degraded pastures in Brazil through sustainable agricultural intensification can reduce the need to open new agricultural frontiers through deforestation of native vegetation.

Pastures recovered by fertilization and re-seeding can have higher yields [15], as well as lower greenhouse gas (GHG) emissions per $\mathrm{kg}$ of beef produced [16]. The area required to produce one $\mathrm{kg}$ of beef carcass in degraded pasture is approximately $320 \mathrm{~m}^{2}$ but falls to $45-50 \mathrm{~m}^{2}$ when grazing receives fertilization [14]. Similarly, grain supplementation can improve animal performance, while decreasing GHG emissions $[13,17,18]$.

The objectives of this study were to (1) evaluate the Integrated Farm System Model (IFSM) using data collected on cooperating farms in both the Amazon and Cerrado biomes and (2) simulate the productive efficiency and environmental impacts of sustainable agricultural intensification (SAI) strategies in the Legal Amazon and in the Cerrado using IFSM. We calibrated and evaluated IFSM for these tropical climates, and this tool can assist in decision-making by farmers comparing pasture re-seeding (PS), pasture fertilization (PF), and grain supplementation (GS). These SAI strategies may have greater potential for adoption by farmers in Mato Grosso and the rest of Brazil compared to rotational grazing and integrated crop-livestock systems as they are less management intensive and are not as dependent on spatial proximity of specialized crop (e.g., soybean) and livestock (e.g., extensive beef) producers.

\section{Materials and Methods}

\subsection{Integrated Farm System Model}

Crop-livestock simulation models reproduce the main agricultural processes to represent the production system statically over time, allowing a more complete evaluation [19]. The Integrated 
Farm System Model (IFSM) is a comprehensive software used to simulate milk and meat production systems for cattle [20]. Current studies of beef production compare different systems and contrast their effects on resource use and production efficiency [21], environmental impact [19,22], and production costs and net return [18]. Sub-models are included to represent all the major processes that occur on farms [23]. Thus, agricultural systems are simulated over many years of meteorological data to determine long-term performance and risk assessment from climatic variation [19].

The IFSM software is organized into six sections that predict nutrient intakes and animal performance. Series of equations are simultaneously solved to obtain an optimal solution for feeding (e.g., grain supplementation and/or pasture). Feed characteristics are defined by the user and available rations are allocated to groups of animals. The intake of nutrients is then established for all groups of animals and used to predict the body growth of animals each month of each simulated year [24]. Based on diet information, the amount and content of nutrients in bovine manure can be determined [20]. Thus, nutrient balances are determined as the sum of all imports of nutrients from feed, fertilizer, deposition and fixation of legumes, subtracting what has been withdrawn by exports of milk, feed, animal production, manure, and losses leaving the farm [25].

Environmental impacts are simulated, including emissions of gases from fertilizers, soil denitrification and leaching. Emissions of carbon dioxide and methane are modeled through their sources and sinks of crops, animals and manure to predict net emissions of greenhouse gases [26]. Greenhouse gas emissions released on-farm include those from food and animals produced and purchased, electricity, fertilizers, pesticides, and machinery [19].

The growth and development of crops and forages are predicted daily based on the availability of water and nutrients in the soil, ambient temperature and solar radiation absorbed by the system [27]. Grazing animals are kept outdoors throughout the year, but pasture growth may not be available for some periods of the year, so feeding strategy is defined by the groups of animals present in the pasture and by the amount of time they have access to the pasture. Thus, the amount of pasture consumed each month is limited by the pasture growth predicted by the model [20]. Simulation of alternative production strategies for a representative farm can identify strategies that balance livestock production and profit with lower environmental impacts [28,29].

\subsection{Representative Farms}

\subsubsection{Cerrado Biome Cooperating Farm}

The cooperating beef farm in the Cerrado has 1389 ha of its own land in the central-southern region of Mato Grosso state (S $15^{\circ} 51^{\prime} 81.9^{\prime \prime}$ W $56^{\circ} 22^{\prime} 26.4^{\prime \prime}$ ) in the municipality of Acorizal (Figure 1), with 930.6 ha used exclusively for livestock and the rest of the area designated as legal forest reserve for permanent preservation of vegetation (33\%).

The cooperating farmers provided comprehensive data on its operations, including property size, equipment and facilities used, forage characteristics, number of animals, food normally purchased or produced on the farm, herd maintenance costs, inputs, and outputs (Table 1). Data were collected from June 2016 to July 2018. The climate of the region is tropical continental always warm with dry winter and rainy summer, with type "Aw" Köppen classification. The performance of the farm was simulated based on the meteorological data collected at the Rain Wise ${ }^{\circledR}$ station from July 2016 to June 2017.

The farm ranches Nelore cattle (Bos indicus), managing breeding, stocker, and finishing cattle (Table 2) in pastures with tropical grass, predominantly Brachiaria brizantha cv. Marandú. The finishing phase is not carried out on-farm. When cattle body weight reaches about $360 \mathrm{~kg}$, they are transferred to a confinement facility $\sim 450 \mathrm{~km}$ away until they reach the ideal slaughter weight. Breeding cows and bulls receive only mineral supplementation. Finishing cattle receive multiple supplements $(0.01 \%$ of body weight) specifically formulated to meet the nutritional requirements during both the wet season (October to April) and dry season (May to September). 


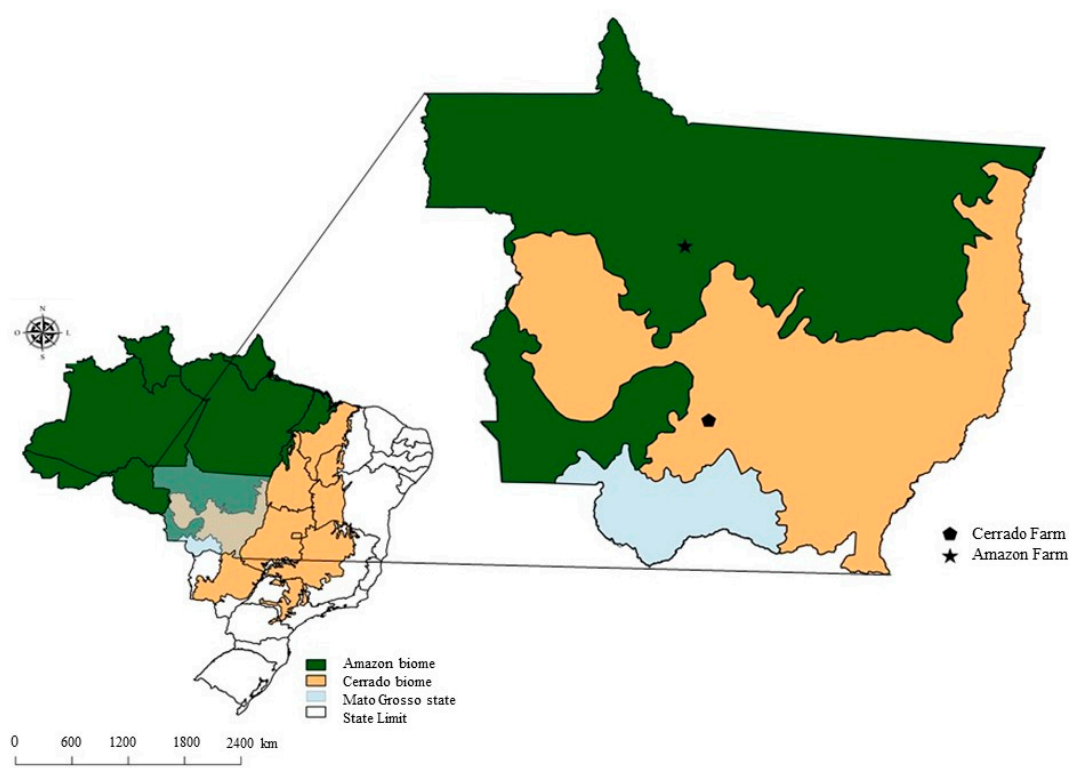

Figure 1. Location of cooperating farms in the Amazonia and Cerrado biome.

Table 1. Production system characteristics for the representative farms in the Cerrado and Amazon biomes, Brazil.

\begin{tabular}{|c|c|c|c|c|c|}
\hline \multirow{2}{*}{ Description } & \multicolumn{2}{|c|}{ Cooperating Cerrado Farm } & \multicolumn{3}{|c|}{ Cooperating Amazon Farm } \\
\hline & 2016-2017 & 2017-2018 & 2015-2016 & 2016-2017 & 2017-2018 \\
\hline \multicolumn{6}{|l|}{ Farm characteristics } \\
\hline Production system & Beef stocker & Beef stocker & Beef finish & Beef finish & Beef finish \\
\hline Pasture type/Crop(s) & $\begin{array}{l}\text { Brachiaria } \\
\text { brizantha } \\
\text { cv. Marandu }\end{array}$ & $\begin{array}{c}\text { Brachiaria } \\
\text { brizantha } \\
\text { cv. Marandu }\end{array}$ & $\begin{array}{l}\text { Brachiaria spp./ } \\
\text { Rice }^{\text {a }}\end{array}$ & $\begin{array}{c}\text { Brach. spp./ } \\
\text { Rice, Soybean a }\end{array}$ & $\begin{array}{l}\text { Brach. spp./ } \\
\text { Soybean a }^{\text {a }}\end{array}$ \\
\hline \multicolumn{6}{|l|}{ Area, ha } \\
\hline Grass & 930.6 & 930.6 & 6147 & 6747 & 6747 \\
\hline Crop $^{a}$ & - & - & 874 & 1214 & 1214 \\
\hline Forest & 343.35 & 343.35 & 16,596 & 16,596 & 16,596 \\
\hline \multicolumn{6}{|l|}{ Soil characteristics } \\
\hline Soil type(s) & $\mathrm{P}^{\mathrm{b}}$ & $\mathrm{P}^{\mathrm{b}}$ & DRYL; $\mathrm{QN}^{\mathrm{b}}$ & DRYL; $\mathrm{QN}^{\mathrm{b}}$ & DRYL; QN ${ }^{b}$ \\
\hline$\%$ sand, silt, clay & $65 \%, 9 \%, 26 \%$ & $65 \%, 9 \%, 26 \%$ & $77 \%, 6 \%, 17 \%$ & $77 \%, 6 \%, 17 \%$ & $77 \%, 6 \%, 17 \%$ \\
\hline $\begin{array}{c}\mathrm{H}_{2} \mathrm{O} \text { capacity }(\mathrm{mm}) \\
\text { Livestock }\end{array}$ & 260 & 260 & 400 & 400 & 400 \\
\hline Breed & $\begin{array}{c}\text { Nelore } \\
\text { (Bos indicus) }\end{array}$ & $\begin{array}{c}\text { Nelore } \\
\text { (Bos indicus) }\end{array}$ & $\begin{array}{c}\text { Nelore } \\
\text { (Bos indicus) }\end{array}$ & $\begin{array}{c}\text { Nelore } \\
\text { (Bos indicus) }\end{array}$ & $\begin{array}{c}\text { Nelore } \\
\text { (Bos indicus) }\end{array}$ \\
\hline Production cycle & $\begin{array}{l}\text { Calves, } \\
\text { replacement }\end{array}$ & $\begin{array}{c}\text { Calves, } \\
\text { replacement }\end{array}$ & Full cycle & Full cycle & Full cycle \\
\hline Diet & $\begin{array}{l}\text { Pasture/ } \\
\text { Supplem. }\end{array}$ & $\begin{array}{l}\text { Pasture/ } \\
\text { Supplem. }\end{array}$ & $\begin{array}{l}\text { Pasture/ } \\
\text { Supplem. }{ }^{c}\end{array}$ & $\begin{array}{l}\text { Pasture/ } \\
\text { Supplem. }\end{array}$ & $\begin{array}{l}\text { Pasture/ } \\
\text { Supplem. }{ }^{c}\end{array}$ \\
\hline Herd, head & 1516 & 2344 & 15,442 & 11,934 & 12,170 \\
\hline \multicolumn{6}{|l|}{ Stocking rate } \\
\hline Head/ha & 1.63 & 2.52 & 2.51 & 1.77 & 1.80 \\
\hline $\mathrm{kg} / \mathrm{ha}$ & 441.35 & 696.14 & 991.84 & 749.36 & 704.26 \\
\hline \multicolumn{6}{|l|}{ Annual production } \\
\hline Arrobas (30 kg/ha) & - & - & 8 & 8.1 & 8.1 \\
\hline $\mathrm{kg} / \mathrm{ha}$ & - & - & 240 & 243 & 243 \\
\hline
\end{tabular}

${ }^{\mathrm{a}}$ Cooperating farm in Amazon used rice and soybeans as cash crops integrated with pasture areas. ${ }^{\mathrm{b}}$ Predominant soil for Cerrado cooperating farm is plinthosol (P). Predominant soil for Amazon cooperating farm is dystrophic red-yellow latosol (DRYL); part of the farmland has quartzarenic neosol $(\mathrm{QN}) \cdot{ }^{\mathrm{C}}$ Low-grain supplementation soybean and corn meal, and cottonseed with minerals for finishing cattle and/or stockers. 
Table 2. Pasture area, beef cattle herd size and stocking rate, fertilization, growth period objectives, cattle feeding and body weight goals for simulations of the extensive beef system, pasture seeding (PS), pasture fertilization (PF), and grain supplementation (GS) in the Cerrado and Amazon biomes, Brazil.

\begin{tabular}{|c|c|c|c|c|}
\hline \multirow{2}{*}{ Parameters } & \multicolumn{4}{|c|}{ Simulated Scenarios in Cerrado and Amazon Biomes } \\
\hline & Extensive & PS & PF & GS \\
\hline \multicolumn{5}{|l|}{ Land area (ha) } \\
\hline Pasture & 1200 & 1200 & 1200 & 1200 \\
\hline Cattle (head) & 1200 & 2400 & 2400 & 2400 \\
\hline Stocking rate (head/ha) & 1.0 & 2.0 & 2.0 & 2.0 \\
\hline \multicolumn{5}{|l|}{ Fertilizer application rate } \\
\hline Nitrogen (kg N/ha) & 0 & 50 & 100 & 0 \\
\hline Phosphate $\left(\mathrm{kg} \mathrm{P}_{2} \mathrm{O}_{5} / \mathrm{ha}\right)$ & 0 & 20 & 50 & 0 \\
\hline Potash $(\mathrm{kg} \mathrm{K} 2 \mathrm{O} / \mathrm{ha})$ & 0 & 20 & 50 & 0 \\
\hline Lime (metric ton/ha/year) & 0 & 1.5 & 1.5 & 0 \\
\hline \multicolumn{5}{|l|}{ Pasture } \\
\hline Re-seeding & No & Yes & No & No \\
\hline Years between re-seeding & $\mathrm{n} / \mathrm{a}$ & 10 & $\mathrm{n} / \mathrm{a}$ & $\mathrm{n} / \mathrm{a}$ \\
\hline Percent (\%) fertilized annually & 0 & 10 & 10 & 0 \\
\hline \multicolumn{5}{|l|}{ Growing period goals (months) } \\
\hline Age of weaning & 8 & 7 & 7 & 7 \\
\hline Stocker period & 11 & 10 & 10 & 10 \\
\hline Backgrounding period & 6 & 0 & 0 & 0 \\
\hline Finishing period & 11 & 7 & 7 & 5 \\
\hline Supplementation & No & No & No & Yes \\
\hline Forage to grain ratio & High & High & High & High \\
\hline \multicolumn{5}{|l|}{ Finish shrunk body weight goals $(\mathrm{kg})$} \\
\hline Initial & 360 & 360 & 360 & 360 \\
\hline Final & 430 & 430 & 430 & 430 \\
\hline
\end{tabular}

Soil samples were collected from all pasture areas during the first half of 2016. About ten to twenty subsamples were collected from pastures. Homogenates and composite samples were sent to the laboratory of the Federal University of Mato Grosso to determine physical and chemical parameters. The cooperating farm's soil type is deep sandy Franco. Pasture fertilization is carried out annually during the summer, according to the nutrient replenishment requirements estimated from soil analyses.

\subsubsection{Amazon Biome Cooperating Farm}

The cooperating beef farm in the Amazon is in the municipality of Porto dos Gaúchos in the state of Mato Grosso (S 11 $44^{\prime} 01.3^{\prime \prime}$ W 56 $\left.6^{\circ} 4^{\prime} 55.7^{\prime \prime}\right)$. In the first year (2015-2016), farm pasture and crop area was 6147 hectares, while, in the second year, 2016-2017, 600 hectares of pasture area were added and 874 hectares were cultivated with soybeans. In the third year, the integrated area was 1214 hectares cultivated with soy.

The cooperating farm is specialized in beef cattle production, more recently diversifying management of pasture and integrating pasture areas with soy and corn. The climate is classified as tropical humid (Athi Köppen classification) with summer rainy season and winter dry season. Common soil types include the dystrophic red latosol and the quartzarenic neosol.

Full animal inventory was collected monthly and during the vaccination campaign for foot-and-mouth disease, in order to determine cattle group characteristics in addition to how the herd has evolved. The average annual beef herd was 15,769 head in 2015-2016, declining to 11,708 head over the next two years. The herd consists mainly of Nelore cattle (Bos indicus), with a stocking rate of 1.8 head per ha in 2017-2018. Brachiaria brizantha spp. and Panicum maximum spp. pastures are used with mineral supplementation for breeding and finishing.

Data collected from July 2015 to June 2018 included farm areas used, resource inventories, technical information on crop and pasture management, such as fertilizer application rates, dates and number of operations, labor demand, grazing period, and pasture quality. Meteorological data (solar radiation, 
precipitation, minimum and maximum temperature) were collected at the Rain Bird ${ }^{\circledR}$ Climate Minder weather station, located on the farm (Figure 1).

\subsection{Cooperating Beef Farms Evaluations}

IFSM models were specifically calibrated to both cooperating farms for each year farm-level production data was collected for the Cerrado (2016-2017 and 2017-2018) and Amazon (2015-2016 through 2017-2018) cooperating farms. IFSM parameters were adjusted to reflect observed livestock production, purchased concentrated feeds, and/or crop yield. Pasture yield was not measured on-farm; rather, this was estimated as a range from $1.8 \%$ to $2.5 \%$ of recommended dry matter intake for each cattle group in the herd [30]. Both biomes had models set for seasonal (spring, summer, fall, and winter) variation in pasture bromatological composition [31]. Due to the complexity of the analysis to measure dry matter intake of the herd, such analyses were not performed.

\subsection{Beef Production Systems Simulations}

Once the IFSM model has been evaluated, it is possible to simulate different strategies for the sustainable agricultural intensification (SAI) of beef production system. Although the cooperating farms present productive differences, the SAI systems used in our simulations are adaptable to farms of varied scale and herd size [32]. The simulated systems were an extensive pasture system used as control, representing the most common system present in both biomes and three systems with SAI: pasture re-seeding (PS), pasture fertilization (PF), and grain supplementation (GS).

IFSM calculates net return (profit) of the meat production system as the sum of all farm revenues minus the sum of all activity-related costs [20]. Revenues include income from animal sales, while costs include purchased feed and activities associated with animal production, such as fuel, facilities, labor, seeds, fertilizers, and chemicals. We also compared relative profitability of all systems assuming annual profits grew at a compound interest rate of $6 \%$. Environmental impacts of beef production systems can also be simulated, such as greenhouse gas emissions and water and energy use, as well as nitrogen footprint. Since actual data on environmental impacts may not be available or quantified, such as the emission of greenhouse gases or the fixation of soil N, estimates can be obtained using models, like IFSM [22], or other computational analyses [13].

Accurate assessment and comparison of advanced systems require the use of a common size, as well as control of variation, in farm characteristics. The area used for all simulations is 1200 hectares, but the stocking rate between the extensive and sustainable agricultural intensification (SAI) systems was different, making the number of animals in the extensive system smaller due to its lower carrying capacity. The extensive stocking rate was 1 head/hectare (ha). Herd inventory was 440 cows and bulls, and 353 replacement, 179 stocker, and 229 finishing cattle.

For SAI simulations, the stocking rate was increased to 2 head/ha, so the herd consisted of 880 cows and bulls, 705 replacement, 358 stockers, and 457 finished cattle. The number of animals was the same in all three SAI simulations to reduce undesirable variability during system comparisons. The simulated breed for all systems in both biomes was the Nelore breed predominant in tropical regions. Months until reaching ideal slaughter weight varied between systems due to differences in diets (Table 3). Calculating carbon footprint, water and energy use, and reactive nitrogen footprint per $\mathrm{kg}$ of edible beef produced assumed beef carcass weight is $52.2 \%$ of beef live weight for Nelore cattle [33]. Human edible feed conversion efficiency (heFCE) for both protein and energy were calculated for all simulated systems by dividing the content for these in beef by the content for these in human edible feed fed to cattle (e.g., corn grain and soybeans) using methods outlined in Ertl et al., 2015 [34]. A ratio of heFCE below one means the animal production system is less efficient corresponding to higher use of feeds that could be eaten by humans (e.g., corn grain, soybeans, etc.). 
Table 3. Actual versus Integrated Farm System Model (IFSM) simulated annual production and purchases for cooperating beef farms in Cerrado and Amazon biomes.

\begin{tabular}{|c|c|c|c|c|c|c|c|c|c|c|}
\hline \multirow{3}{*}{ Beef System Output } & \multicolumn{4}{|c|}{ Cooperating Cerrado Farm } & \multicolumn{6}{|c|}{ Cooperating Amazon Farm } \\
\hline & \multicolumn{2}{|c|}{ 2016-2017 } & \multicolumn{2}{|c|}{ 2017-2018 } & \multicolumn{2}{|c|}{ 2015-2016 } & \multicolumn{2}{|c|}{ 2016-2017 } & \multicolumn{2}{|c|}{ 2017-2018 } \\
\hline & Actual & Simulated & Actual & Simulated & Actual & Simulated & Actual & Simulated & Actual & Simulated \\
\hline $\begin{array}{l}\text { Grazed pasture } \\
\text { (t DM/ha) }\end{array}$ & - & 3.03 & - & 4.89 & - & 3.66 & - & 2.97 & - & 1.79 \\
\hline \multicolumn{11}{|c|}{ Calculated ${ }^{a}$ forage DMI required ( $\mathrm{DM} / \mathrm{ha}$ ) } \\
\hline Minimum at $1.8 \%$ & 2.99 & - & 4.64 & - & - & - & - & - & - & - \\
\hline Maximum at $2.5 \%$ & 4.15 & - & 6.44 & - & $3.94^{\mathrm{a}}$ & - & $2.89^{\mathrm{a}}$ & - & $2.37^{\mathrm{a}}$ & - \\
\hline \multicolumn{11}{|l|}{ Production (t DM/ha) } \\
\hline $\begin{array}{c}\text { Soybean } \\
\text { Purchases (t DM/ha) }\end{array}$ & \multicolumn{9}{|c|}{ Purchases (t DM/ha) } & 2.15 \\
\hline Forage & - & 0.90 & - & 1.68 & - & 0.57 & 0.31 & 0.34 & 0.47 & 0.30 \\
\hline Corn grain & 0.21 & 0.18 & 0.34 & 0.22 & 0.48 & 0.52 & 0.30 & 0.16 & 0.35 & 0.19 \\
\hline Cottonseed & - & - & - & - & 0.03 & 0.04 & - & - & - & - \\
\hline Soybean, $44 \%$ protein & 0.19 & 0.24 & 0.30 & 0.29 & 0.14 & 0.18 & 0.10 & 0.14 & 0.08 & 0.24 \\
\hline Minerals & 0.25 & 0.18 & 0.41 & 0.03 & 0.02 & 0.02 & 0.02 & 0.02 & 0.01 & 0.01 \\
\hline $\begin{array}{l}\text { Grazed pasture } \\
\text { (t DM/head) }\end{array}$ & - & 2.19 & - & 1.43 & - & 5.60 & - & 6.11 & - & 3.61 \\
\hline \multicolumn{11}{|l|}{$\begin{array}{l}\text { Calculated a forage DMI } \\
\text { required (t DM/head) }\end{array}$} \\
\hline Minimum at $1.8 \%$ & 1.83 & - & 1.97 & - & - & - & - & - & - & - \\
\hline Maximum at $2.5 \%$ & 2.55 & - & 2.74 & - & $6.03^{\mathrm{a}}$ & - & $5.95^{\mathrm{a}}$ & - & $4.78^{\mathrm{a}}$ & - \\
\hline \multicolumn{11}{|l|}{ Purchases (t DM/head) } \\
\hline Forage & - & 0.55 & - & 0.66 & - & 0.87 & 0.64 & 0.70 & 0.95 & 0.61 \\
\hline Corn grain & 0.13 & 0.11 & 0.14 & 0.86 & 0.73 & 0.80 & 0.62 & 0.33 & 0.71 & 0.38 \\
\hline Soybean, $44 \%$ protein & 0.11 & 0.14 & 0.12 & 0.12 & 0.21 & 0.28 & 0.21 & 0.29 & 0.16 & 0.48 \\
\hline Minerals & 0.16 & 0.11 & 0.16 & 0.01 & 0.03 & 0.03 & 0.04 & 0.04 & 0.02 & 0.02 \\
\hline $\begin{array}{l}\text { Beef production } \\
(\mathrm{kg} \mathrm{BW} / \mathrm{ha})\end{array}$ & - & - & - & - & 231 & 267 & 243 & 236 & 289 & 248 \\
\hline
\end{tabular}

${ }^{\text {a }}$ For cooperating farm in Cerrado biome, calculated from National Research Council (NRC) dry matter intake (DMI) requirements for beef cattle at daily DMI per cattle body weight of

$1.8 \%$ (minimum) and $2.5 \%$ (maximum). For cooperating farm in Amazon biome, calculated from NRC dry matter intake (DMI) requirements for beef cattle at daily DMI/cattle body weight of $2.5 \%$. 
All simulated systems provided minerals for cattle and used a $108 \mathrm{hp}(80 \mathrm{~kW})$ tractor priced at US\$7693. Extensive system pasture received no fertilization. Pasture stand life was 10 years before plowing (November 10) and re-seeding (PS), fertilized with 50-20-20 NPK kg/ha with lime application at $1 \mathrm{t} / \mathrm{h}$. PS used a medium-sized tractor with fuel consumption of $33.5 \mathrm{~L} / \mathrm{ha}(13.4 \mathrm{~L} / \mathrm{h}$ at $2.5 \mathrm{~h} / \mathrm{ha})$ based on re-seeding costs of US\$169/ha [35]. Pasture utilization efficiency was set to $66 \%$ for the establishment year. Only $10 \%$ of pasture is fertilized (PF) each year at 100-50-50 NPK kg/ha and $1.5 \mathrm{t}$ lime/ha. Pasture fertilization levels were surveyed from cooperating producers. For the grain supplementation (GS) simulation, cows, heifers, and stockers were fed at a supplementation level to meet $45 \%$ of recommended protein requirements [30]. Other costs and economic parameters are summarized in Supplementary Materials (Tables S1 and S2).

IFSM beef farm simulations for the Cerrado and Amazon biomes only differed by climatic conditions (Figure 2) and soil characteristics (Table 1). IFSM simulations are annual and not dynamically linked. Annual weather data measured from both on-farm meteorological stations in the Cerrado (2 years, 2016-2018) and Amazon (3 years, 2015-2018) biomes were supplemented with historical weather data from nearby weather stations in the Cerrado (Cuiabá, 69\% of daily weather observations) and Amazon (Juara, 6\% of daily weather observations) downloaded from the Instituto Nacional de Metereologia (INMET) or National Institute of Meteorology. This historical weather data (2007-2018) were used for IFSM simulations and included precipitation, solar radiation, relative humidity, and wind speed. Cuiabá was limited to 2012-2018 due to a lack of available data.

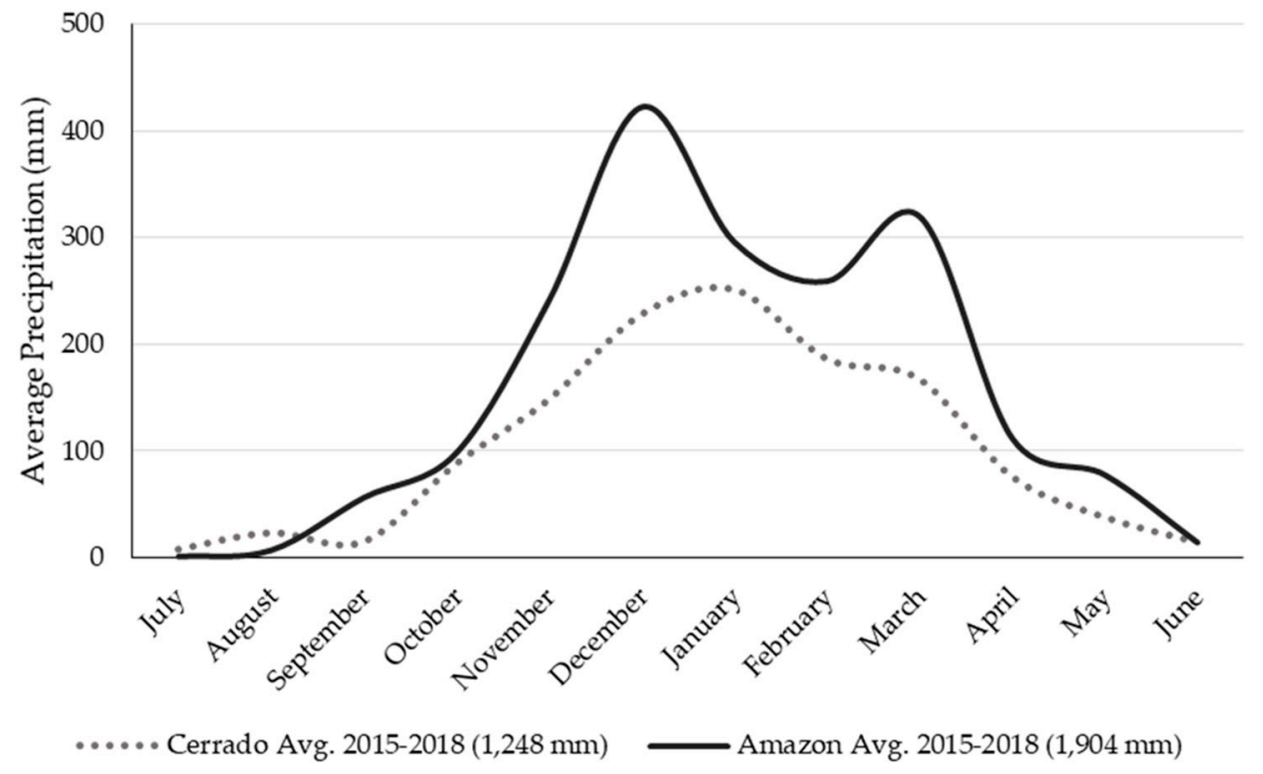

Figure 2. Average precipitation at cooperating farm and Cuiabá weather station in the Cerrado biome and average precipitation at cooperating farm weather station in the Amazon biome over three production years (2015-2018).

\section{Results}

\subsection{Cooperating Farms Weather Stations}

The cooperating farm in the Cerrado biome had an annual average (2016-2017 and 2017-2018) temperature of $25^{\circ} \mathrm{C}$ (minimum $20^{\circ} \mathrm{C}$ and maximum $30^{\circ} \mathrm{C}$ ) and wind speed $2.5 \mathrm{~m} / \mathrm{s}$. Solar radiation was not collected but averaged $12.4 \mathrm{MJ} / \mathrm{m}^{2}$ over these two years at the nearby Cuiabá weather station. The average precipitation for the combined observations from the cooperating farm and Cuiabá weather stations averaged $1248 \mathrm{~mm} /$ year from 2015-2018. For the Amazon biome cooperating farm from 2015-2016 through 2017-2018, average temperature was $28^{\circ} \mathrm{C}$ (minimum $17{ }^{\circ} \mathrm{C}$ and maximum $39{ }^{\circ} \mathrm{C}$ ), with averages for rainfall at $1904 \mathrm{~mm} /$ year, solar radiation at $17.1 \mathrm{MJ} / \mathrm{m}^{2}$, and wind speed 
averaged $1.2 \mathrm{~m} / \mathrm{s}$ [36]. Average Amazon precipitation exceeded that in the Cerrado for most of the year (Figure 2).

\subsection{Beef Production Systems Evalution}

The simulated values for forage intake were generally lower than calculated values for the farm. Forage grasses present in tropical climate conditions (predominantly Brachiaria brizantha cv. Marandu) are adapted to the low rainfall during the dry season. IFSM optimally solved for increased supplemental feeding of forage rather than pasture grazing during this time. In reality, cattle continue to graze forage of lower nutritional quality, where its bromatological value is corrected by supplementation. Adjustments were made to narrow the gap between simulated and actual intake feeds, including reducing absorbent protein requirements by $10 \%$ [37].

\subsubsection{Cerrado Biome Evaluation}

From 2016-2018, the cooperating farm's beef herd and feed purchases were relatively stable. The simulated values for forage intake ( $\mathrm{t} \mathrm{DM} / \mathrm{ha}$ ) were between the estimated minimum and maximum values, representing $73 \%$ and $76 \%$ of the maximum value calculated for the farm for 2016-2017 and 2017-2018, respectively. For the purchase of corn grain and soybean meal (t DM/ha), the simulated value was 105\% of actual for 2016-2017 and 80\% of observed for the cooperating farm in 2017-2018 (Table 3). In the second year (2017-2018), cattle stocking rate increased from 1.63 to 2.52 head/ha (Table 1) due to pasture fertilization and greater grain and protein intake.

\subsubsection{Amazon Biome Evaluation}

Simulated dry matter intake of forage by IFSM was $93 \%, 103 \%$, and $76 \%$ of the values calculated for the cooperating farm across all three years (2015-2016 through 2017-2018). Simulated corn grain, cottonseed, and soybean purchases were $114 \%, 75 \%$, and 100\% of actual (Table 3). To meet dietary requirements of cattle, IFSM's linear program solved for greater purchase of forage and grains instead of grazing during the dry season, due to low pasture production from lack of rain. In reality, pasture is used by cattle during the dry season. Thus, IFSM underestimated pasture dry matter intake while overestimating purchased concentrated feed.

IFSM simulated soybean yields were $109 \%$ and 103\% of observed soybean yields for 2016-2017 and 2017-2018, respectively (Table 3). These small differences may be due to variations in the chemical or physical parameters of the farm's soils. The simulated production for beef was $116 \%$ of observed production for the first year (2015-2016) since the animals spent more time to reach the ideal body weight for slaughter. In the second year (2016-2017), due to better climatic conditions and lower stocking rate associated with the integration of $13 \%$ of farm area with no-tillage, pastures improved where simulated beef production ( $\mathrm{kg} \mathrm{BW} / \mathrm{ha}$ ) was $97 \%$ of observed. Simulated beef production in the third year (2017-2018) was $86 \%$ of observed (Table 3 ). The number of cattle in the herd was higher in 2015-2016, while precipitation was lower compared to the other years. This resulted in lower forage mass production and thus higher grazing pressure. More land was leased the following year to reduce stocking density and silage was purchased for feeding.

\subsection{Production Performance of Simulated Beef Production Systems}

For Cerrado biome simulations, extensive grazed forage intake (1.61 t DM/head/year) was low due to less forage mass for cattle. Pasture re-seeding (PS) and pasture fertilization (PF) were higher at 1.71 and $1.70 \mathrm{DM} /$ head/year, respectively. Both pasture intensification systems supplied nutrients to the soil, allowing greater productivity of the forage mass and, consequently, greater availability for consumption by the animals. Grain supplementation (GS) reduced forage intake to $1.56 \mathrm{t} \mathrm{DM} / \mathrm{head} / \mathrm{year}$ and increased feeding of concentrates (including soybean meal, 44\%) three- to four-fold compared to the extensive baseline model (Table 4). Amazon biome simulations followed a similar pattern for forage intake (t DM/head/year) for extensive (1.74), PS and PF (1.77), and GS (1.63). In order to balance 
the nutritional requirements for the herd in IFSM's linear programming, grain and forage purchases were made for all simulations.

Due to the better productive performance of the animals under GS, average daily gain was greater for both biomes (Table 4). Net gain of body weight at time of slaughter $(\mathrm{kg} / \mathrm{ha} / \mathrm{year})$ of cattle in the Cerrado was greater for GS (300) than both PS and PF (281) in addition to extensive grazing (123). Amazon beef simulations had similar animal productivity $(\mathrm{kg} / \mathrm{ha} / \mathrm{year})$ increases from extensive (124) to PS and PF (280) to GS (301). Extensive grazing's beef productivity was lower due to pasture with lower nutritional value and lower gains, as well as reduced pasture support capacity, preventing higher stocking rates. Beef productivity per $t$ of feed input (pasture, purchased forages, and concentrated feed) was greater for grain supplementation compared to other systems (Table 4).

If we consider this meat production for human consumption, we can quantify the importance of intensifying production in the same area. The global projection for per capita consumption of meat in 2028 is $35.1 \mathrm{~kg} /$ person/year [38]. Considering the increase in meat production in the strategies we evaluated, GS would produce $92 \mathrm{~kg}$ of meat CW/ha more than the extensive system, so it is possible to feed about 2.63 more people per hectare. For the PS and PF systems, meat production was $82 \mathrm{~kg} / \mathrm{ha}$ more than extensive, corresponding to 2.35 more people fed per hectare compared to extensive grazing. Human edible feed conversion efficiency (heFCE) was below one and thus less efficient for the GS system for both protein (0.28 to 0.30) and energy (0.16) content. Pasture re-seeding, pasture fertilization, and extensive grazing had heFCE values greater than one for protein but less than one for energy. GS's heFCE was $87 \%$ to $94 \%$ lower for protein and $60 \%$ to $79 \%$ lower for energy compared to other systems (Table 5).

Table 4. Simulated pasture and feed consumption in IFSM for the extensive beef system, pasture seeding (PS), pasture fertilization (PF), and grain supplementation (GS) in the Cerrado and Amazon biomes, Brazil.

\begin{tabular}{|c|c|c|c|c|c|c|c|c|}
\hline \multirow{2}{*}{$\begin{array}{l}\text { Output of Simulated } \\
\text { Beef Systems }\end{array}$} & \multicolumn{4}{|c|}{ Cerrado Simulations } & \multicolumn{4}{|c|}{ Amazon Simulations } \\
\hline & Extensive & PS & PF & GS & Extensive & PS & PF & GS \\
\hline $\begin{array}{l}\text { Grazed forage consumed } \\
\text { (t DM/ha) }\end{array}$ & 1.61 & 3.41 & 3.39 & 3.11 & 1.74 & 3.55 & 3.53 & 3.26 \\
\hline \multicolumn{9}{|l|}{ Purchased } \\
\hline Forage (t DM/ha) & 0.52 & 1.25 & 1.26 & 1.24 & 0.30 & 1.03 & 1.03 & 1.02 \\
\hline Grain (t DM/ha) & 0.04 & 0.06 & 0.06 & 0.13 & 0.03 & 0.05 & 0.06 & 0.12 \\
\hline Soybean meal (t DM/ha) & - & - & - & 0.11 & - & - & - & 0.13 \\
\hline $\begin{array}{l}\text { Mineral \& vitamin mix } \\
\text { (t DM/ha) }\end{array}$ & 0.01 & 0.02 & 0.02 & 0.02 & 0.01 & 0.02 & 0.02 & 0.02 \\
\hline $\begin{array}{l}\text { Grazed forage \& purchased feed } \\
\text { input (t DM/ha) }{ }^{\text {a }}\end{array}$ & 12.17 & 34.72 & 34.71 & 34.59 & 12.07 & 34.63 & 34.62 & 34.53 \\
\hline $\begin{array}{l}\text { Grazed forage consumed (t DM/head) } \\
\text { Purchased }\end{array}$ & \multicolumn{7}{|c|}{ Purchased } & 1.63 \\
\hline Forage (t DM/head) & 0.52 & 0.63 & 0.63 & 0.62 & 0.30 & 0.52 & 0.52 & 0.51 \\
\hline Grain (t DM/head) & 0.04 & 0.03 & 0.03 & 0.07 & 0.03 & 0.02 & 0.03 & 0.06 \\
\hline Soybean meal (t DM/head) & - & - & - & 0.06 & - & - & - & 0.06 \\
\hline Mineral and vitamin mix (t DM/head) & 0.01 & 0.01 & 0.01 & 0.01 & 0.01 & 0.01 & 0.01 & 0.01 \\
\hline $\begin{array}{l}\text { Grazed forage \& purchased feed } \\
\text { input }(\mathrm{t} \mathrm{DM} / \text { head })^{\text {a }}\end{array}$ & 12.17 & 32.37 & 32.36 & 32.31 & 12.07 & 32.31 & 32.32 & 32.26 \\
\hline $\begin{array}{l}\text { Net animal weight sold } \\
(\mathrm{kg} \mathrm{BW} / \mathrm{ha})\end{array}$ & 123 & 281 & 281 & 300 & 124 & 280 & 280 & 301 \\
\hline (kg CW/ha) & 64 & 147 & 147 & 157 & 65 & 146 & 146 & 157 \\
\hline $\begin{array}{l}\text { Net animal weight sold per feed input } \\
\qquad(\mathrm{kg} \mathrm{BW} / \mathrm{t} \mathrm{DM})\end{array}$ & 56.7 & 59.5 & 59.7 & 65.4 & 59.9 & 60.5 & 60.6 & 66.5 \\
\hline$(\mathrm{kg} \mathrm{CW/t} \mathrm{DM)}$ & 29.6 & 31.1 & 31.1 & 34.1 & 31.3 & 31.6 & 31.6 & 34.7 \\
\hline
\end{tabular}

${ }^{\text {a }}$ Does not include mineral and vitamin mix. 
Table 5. Human edible feed conversion efficiency calculations for the extensive beef system, pasture seeding (PS), pasture fertilization (PF), and grain supplementation (GS) in the Cerrado and Amazon biomes, Brazil.

\begin{tabular}{|c|c|c|c|c|c|c|c|c|}
\hline \multirow{2}{*}{$\begin{array}{c}\text { Calculations of Simulated Beef } \\
\text { Systems }\end{array}$} & \multicolumn{4}{|c|}{ Cerrado Simulations } & \multicolumn{4}{|c|}{ Amazon Simulations } \\
\hline & Extensive & PS & PF & GS & Extensive & PS & PF & GS \\
\hline \multicolumn{9}{|l|}{$\begin{array}{c}\text { Human edible feed conversion } \\
\text { efficiency (heFCE) } \\
\text { Protein }\end{array}$} \\
\hline Saleable meat (kg/ha) & 48 & 109 & 109 & 116 & 48 & 108 & 108 & 116 \\
\hline Beef protein sold (kg/ha) & 9.0 & 20.6 & 20.6 & 22.0 & 9.1 & 20.6 & 20.6 & 22.1 \\
\hline Grain (kg DM/ha) & 40 & 60 & 60 & 130 & 30 & 50 & 60 & 120 \\
\hline Grain protein $(\mathrm{kg} / \mathrm{ha})$ & 3.8 & 5.6 & 5.6 & 12.2 & 2.8 & 4.7 & 5.6 & 11.3 \\
\hline Soybean meal (kg DM/ha) & 0 & 0 & 0 & 110 & 0 & 0 & 0 & 130 \\
\hline Soybean meal protein $(\mathrm{kg} / \mathrm{ha})$ & 0 & 0 & 0 & 57.0 & 0 & 0 & 0 & 67.3 \\
\hline Total Feed Protein (kg protein/ha) & 3.8 & 5.6 & 5.6 & 69.2 & 2.8 & 4.7 & 5.6 & 78.6 \\
\hline $\begin{array}{c}\text { heFCE }=\text { Beef protein/Human } \\
\text { edible feed protein } \\
\text { Energy }\end{array}$ & 2.40 & 3.66 & 3.66 & 0.32 & 3.23 & 4.37 & 3.64 & 0.28 \\
\hline Saleable meat (kg/ha) & 48 & 109 & 109 & 116 & 48 & 109 & 109 & 116 \\
\hline Beef energy sold (MJ/ha) & 308 & 703 & 703 & 751 & 310 & 701 & 701 & 753 \\
\hline Grain (kg DM/ha) & 40 & 60 & 60 & 130 & 30 & 50 & 60 & 120 \\
\hline Grain energy (MJ/ha) & 748 & 1122 & 1122 & 2431 & 561 & 935 & 1122 & 2244 \\
\hline Soybean meal (kg DM/ha) & 0 & 0 & 0 & 110 & 0 & 0 & 0 & 130 \\
\hline Soybean meal energy (MJ/ha) & 0 & 0 & 0 & 2167 & 0 & 0 & 0 & 2561 \\
\hline Total Feed Energy (MJ/ha) & 748 & 1122 & 1122 & 4598 & 561 & 935 & 1122 & 4805 \\
\hline $\begin{array}{c}\text { heFCE = Beef energy/Human } \\
\text { edible feed energy }\end{array}$ & 0.41 & 0.63 & 0.63 & 0.16 & 0.55 & 0.75 & 0.62 & 0.16 \\
\hline
\end{tabular}

\subsection{Profitability of Simulated Beef Production Systems}

For Cerrado and Amazon beef simulations, the cost of production per hectare (ha) was lowest for extensive, followed by grain supplementation, pasture re-seeding, and pasture fertilization. However, for Cerrado beef simulations since revenues were lower, the extensive system had a lower net return (US\$22.86 ha/year) compared to the three sustainable agricultural intensification (SAI) strategies, due to lower animal stocking rate and lower beef productivity. Net returns increased with PS (US\$61.08 ha/year) and PF (US\$65.69 ha/year), with the highest net return for GS (US\$92.26 ha/year). Amazon beef simulations were similar with net returns per ha per year lowest for extensive (US\$24.28 ha/year), followed by PS (US\$64.26 ha/year), PF (US\$66.75 ha/year), and then highest for GS (US\$90.01 ha/year). While all three SAI strategies have similar revenues, GS was more profitable compared to PS and PF due to lower crop production and animal purchases, despite higher cost of purchased feed (Table 6). The relative profitability of all systems did not change when comparing annual profits growing at a compound interest rate of $6 \%$ for each system.

\subsection{Environmental Impacts}

For all systems evaluated in both biomes (Table 7), the main sources of greenhouse gas (GHG) emissions were from cattle. Extensive grazing presented the largest carbon footprint in both biomes. In the Cerrado biome, the carbon footprint $\left(\mathrm{CF}\right.$ in $\mathrm{kgCO} / 2 \mathrm{eq} / \mathrm{kg}$ body weight or $\mathrm{kgCO}_{2} \mathrm{eq} / \mathrm{kg}$ carcass weight) for grain supplementation was $84 \%$ of the CF for the extensive baseline scenario. GS had the lowest CF due to higher feed efficiency resulting in reduced emissions per $\mathrm{kg}$ of beef body weight (BW) and per kg of beef carcass weight. Pasture re-seeding and pasture fertilization had higher CF than GS due to accumulated emissions to produce and apply fertilizers and other inputs in addition to greater methane emissions from cattle (Supplementary Materials, Tables S3 and S4). Amazon biome CF results were similar with the CF of GS also $84 \%$ of extensive. PS and PF also had greater CF's than GS. Emissions per hectare for sustainable agricultural intensification strategies were more than double than extensive due to doubled stocking density (Table 7). 
Table 6. Revenues, costs, and returns simulated in IFSM for the extensive beef system, pasture seeding (PS), pasture fertilization (PF), and grain supplementation (GS) in the Cerrado and Amazon biomes, Brazil.

\begin{tabular}{|c|c|c|c|c|c|c|c|c|}
\hline \multirow{2}{*}{$\begin{array}{c}\text { Output of Simulated Beef } \\
\text { Systems }\end{array}$} & \multicolumn{4}{|c|}{ Simulated Scenarios in Cerrado } & \multicolumn{4}{|c|}{ Simulated Scenarios in Amazon } \\
\hline & Extensive & e PS & PF & GS & Extensive & PS & PF & GS \\
\hline \multicolumn{9}{|l|}{ Farm revenues (US\$/y) } \\
\hline From animal sales & 208,846 & 438,767 & 438,467 & 436,917 & 209,048 & 439,520 & 439,520 & 436,790 \\
\hline Farm revenues (US\$/ha/y) & 174.04 & 365.64 & 365.39 & 364.10 & 174.21 & 366.27 & 366.27 & 363.99 \\
\hline \multicolumn{9}{|l|}{ Production costs (US\$/ha/y) } \\
\hline Equipment & 33.14 & 47.52 & 34.51 & 33.14 & 33.14 & 47.52 & 34.51 & 33.14 \\
\hline Facilities & 0 & 1.29 & 1.29 & 2.61 & 0 & 1.29 & 1.29 & 2.61 \\
\hline Energy & 5.53 & 10.71 & 9.54 & 7.77 & 5.53 & 10.71 & 9.54 & 7.77 \\
\hline Labor & 12.28 & 29.33 & 29.21 & 20.00 & 11.37 & 27.50 & 27.31 & 19.09 \\
\hline Seed, fertilizer, chemicals & 0 & 31.30 & 42.86 & 10.56 & 0 & 31.30 & 42.86 & 10.56 \\
\hline Purchased feeds & 7.15 & 14.15 & 14.65 & 51.58 & 6.63 & 13.62 & 13.94 & 54.63 \\
\hline $\begin{array}{l}\text { Animal purchase \& } \\
\text { livestock expense }\end{array}$ & 62.19 & 136.66 & 136.66 & 115.11 & 62.37 & 139.09 & 139.09 & 115.11 \\
\hline Property tax & 30.89 & 30.98 & 30.98 & 31.07 & 30.89 & 30.98 & 30.98 & 31.07 \\
\hline Total cost (US\$/ha/y) & 151.18 & 301.94 & 299.70 & 271.84 & 149.93 & 302.01 & 299.52 & 273.98 \\
\hline Net return (US\$/ha/y) & 22.86 & 63.70 & 65.69 & 92.26 & 24.28 & 64.26 & 66.75 & 90.01 \\
\hline
\end{tabular}

Table 7. Annual average emissions of total greenhouse gases (GHG) and natural resource use per hectare simulated in IFSM for the extensive beef system, pasture seeding (PS), pasture fertilization (PF), and grain supplementation (GS) in the Cerrado and Amazon biomes, Brazil.

\begin{tabular}{ccccccccc}
\hline \multirow{2}{*}{ Impacts of Simulated Beef Systems } & \multicolumn{3}{c}{ Cerrado Simulations } & \multicolumn{4}{c}{ Amazon Simulations } \\
\cline { 2 - 9 } & Extensive & PS & PF & GS & Extensive & PS & PF & GS \\
\hline Greenhouse Gas (GHG) Emissions & & & & & & & & \\
Total GHG emissions (kg CO 2 eq/ha) & 2376 & 5104 & 5153 & 4876 & 2339 & 4909 & 4942 & 4793 \\
Carbon footprint (kg CO 2 eq/kg BW) & 19.26 & 18.15 & 18.32 & 16.25 & 18.91 & 17.50 & 17.62 & 15.93 \\
Carbon footprint (kg CO 2 eq/kg CW) & 36.90 & 34.77 & 35.10 & 31.13 & 36.23 & 33.52 & 33.75 & 30.52 \\
Water Use & & & & & & & & \\
Feed, drinking, \& production (Mg/ha) & 8368 & 7960 & 7904 & 9288 & 13,071 & 12,916 & 12,969 & 13,844 \\
Water footprint w/o rain (kg/kg BW) & 3340 & 3403 & 3450 & 3769 & 2049 & 2825 & 2852 & 3256 \\
Water footprint w/o rain (kg/kg CW) & 6398 & 6519 & 6609 & 7220 & 3925 & 5412 & 5464 & 6238 \\
Energy Use & & & & & & & & \\
Feed \& resource inputs (MJ/ha) & 1496 & 3888 & 4240 & 3567 & 194 & 3428 & 3764 & 3139 \\
Energy footprint (MJ/kg BW) & 13.26 & 14.68 & 15.94 & 12.59 & 9.60 & 13.08 & 14.27 & 11.14 \\
Energy footprint (MJ/kg CW) & 25.40 & 28.12 & 30.54 & 24.12 & 18.39 & 25.06 & 27.34 & 21.34 \\
Reactive Nitrogen (N) Loss & & & & & & & & \\
Total nitrogen losses (kg/ha) & 27.61 & 70.17 & 74.16 & 58.33 & 27.52 & 54.18 & 57.36 & 57.20 \\
Reactive nitrogen footprint (g/kg BW) & 223.0 & 248.8 & 263.0 & 194.6 & 221.9 & 193.6 & 204.9 & 189.8 \\
Reactive N footprint (g/kg CW) & 427.2 & 476.6 & 503.8 & 372.8 & 425.1 & 370.9 & 392.5 & 363.6 \\
\hline
\end{tabular}

Water footprint $(\mathrm{kg} / \mathrm{kg}$ BW or $\mathrm{kg} / \mathrm{kg} \mathrm{CW})$ for both biomes is greatest for GS. More dietary concentrated feed increased total water consumption by cattle. More water was also needed for grain supplement production. Other systems (PS, PF, and extensive) had water footprints that are only a certain percentage of GS. For the Cerrado biome, this ranged from $87 \%$ to $92 \%$, while in the Amazon this was 63\% to $88 \%$ (Table 7). PS and PF has 5\% to $13 \%$ less water use for pastures (Supplementary Materials, Table S4). Water use per hectare was greatest for GS followed by extensive and then pasture fertilization and pasture re-seeding (Table 7).

Energy footprint $(\mathrm{EF}=\mathrm{MJ} / \mathrm{kg} \mathrm{BW}$ or $\mathrm{MJ} / \mathrm{kg} \mathrm{CW})$ includes all energy entering the system, directly and indirectly, responsible for beef production. Across both biomes, Cerrado PF had both the highest energy use per area (4240 MJ/ha) and highest EF due to fertilizers applied to pastures providing a greater energy input to the system, which was $9 \%$ to $27 \%$ greater than the other systems. GS had the lowest EF. Results were similar for the Amazon biome where the EF for PF was 9\% to 47\% greater than 
other systems. GS also had the lowest EF of all systems. Energy use per hectare was greatest for PF, PS, and GS followed by extensive (Table 7).

Nitrogen losses were at least double to almost triple for the three sustainable agricultural intensification systems ( $\sim 54-74 \mathrm{~kg} / \mathrm{ha})$ compared to extensive pasture $(\sim 28 \mathrm{~kg} / \mathrm{ha})$. Reactive nitrogen footprint for both biomes was lowest for grain supplementation. For the Cerrado biome, GS was $74 \%$ to $87 \%$ of the reactive nitrogen footprint (RNF) of the other systems. Similarly, for the Amazon biome, GS was $86 \%$ to $98 \%$ of the RNF of other systems. Nitrogen losses per ha were greatest for PF, then PS, followed by GS and extensive grazing (Table 7).

\section{Discussion}

\subsection{Sustainable Agricultural Intensification's Beef Productivity, Feed Conversion Efficiency, and Profitability}

To meet the growing demand for food, cattle herds are expected to increase $73 \%$ by 2050 . Given this increase, there would be no "pioneer frontiers" to convert into agriculture [39]. Brazilian agricultural production could increase without further deforestation and conversion of natural habitat to beef production [40]. Simulated beef weight sold at maturity (kg/ha/year) in the Cerrado and Amazon increased from extensive natural pasture ( 124) to pasture re-seeding and fertilization ( 280) to grain supplementation $(\sim 300)$. Thus, adopting the sustainable agricultural intensification strategies we evaluated can increase beef production from $126 \%$ to $144 \%$.

In extensive systems with pasture degradation, beef production can be as low as $40-50 \mathrm{~kg} / \mathrm{ha} / \mathrm{year}$ with dry season stocking rate less than $0.5 \mathrm{head} / \mathrm{ha}[41,42]$. Our productivity results for the extensive model were double to triple this productivity range since pastures were not at an advanced stage of degradation. For our IFSM simulations, decline in dry season pasture production was compensated by forage purchases via the model's linear programming (Table 4). IFSM does not allow for changing stocking density (e.g., 1 head/ha for extensive simulations) in the same calendar year. Instead of feeding purchased forage during the dry season, Brazilian ranchers can reduce stocking rate thus distributing cattle over more pasture area (e.g., 0.5 head/ha).

Our simulated beef production increase of $\sim 127 \%$ for pasture re-seeding (PS) was greater than the $107 \%$ increase modeled using linear programming for Nelore in nearby Mato Grosso do Sul state [43]. It was also within projected Amazon Nelore production increases of $100 \%$ to $251 \%$ after 6 to 12 years of pasture restoration in Pará state [44] and close to $130 \%$ to $150 \%$ measured for Acre state [45]. Our results were consistent with prior research [32], where, compared with the extensive system, pasture systems using intensification strategies had higher costs, but beef production almost doubled with combined intensification techniques including pasture fertilization [32]. Our modeled strategies had higher production costs, but meat production and profitability were also higher than extensive, as system intensification is required to achieve higher slaughter weight and carcass yield which dilutes costs per $\mathrm{kg}$ of beef [46].

Optimal pasture fertilization (PF) improves pasture stands insuring complete coverage of soil by forage in its productive stage given adjustments to stocking rates in dry versus wet seasons [41]. For Nelore cross-bred cattle in the Cerrado, forage availability of one-year-old pasture was $197 \%$ greater than 20-year-old pasture, allowing for a stocking rate of 3 head/ha [47]. Our results were consistent with this, where PF's yield and forage supply during the simulation's first year was $\sim 245 \%$ greater in Amazon and Cerrado biomes compared to extensive pasture.

Grain supplementation (GS) can correct grazing nutritional deficiencies, decrease grazing pressure, and improve cattle performance and reducing time to slaughter [48]. In tropical regions with low rainfall during the dry season, pasture production decreases. Grain supplementation allows animal productivity to remain constant during the dry season, avoiding weight loss during this time. Compared with the extensive system, our GS age at slaughter was reduced by four months for PF and PS and 6 months for GS. GS had the highest yield ( $\sim 300 \mathrm{~kg} / \mathrm{ha} /$ year $)$ among modeled systems. Farms in the Amazon that adopted supplementation for Nelore cattle reduced slaughter age by 3.4 months 
and increased slaughter rates [16]. In the Cerrado, when forage was improved and supplementation provided, Nelore cross-bred cattle growth rate increased while total annual dry matter intake decreased due to better forage quality and digestibility [14].

Despite greater beef production, the GS system used more human edible protein and energy from corn grain and soybeans to feed the herd, which are feed sources that compete with human food. Thus, even though GS produced more beef per hectare (Table 4), less total food may be available to humans. GS had human edible feed conversion efficiency (heFCE) below the other beef systems for both protein and energy (Table 5), indicating a net reduction in potential human food driven by greater use of human edible feed to produce animal products. Thus, from a heFCE perspective, beef production that is more grass-based is more favorable than systems like GS feeding more human edible concentrated feed inputs. Our heFCE ratios for protein were comparable to those estimated for the U.S. beef industry [49] with our extensive and improved pasture systems (2.4 to 4.37) less than U.S. beef stockers (5.22) and our GS system (0.28 to 0.32) similar to U.S industrial feedlots (0.34). Despite lower beef production per hectare than GS (Table 4), pasture intensification may provide a net gain in human food supply since it uses less concentrated feeds that can been eaten by humans.

Our simulations' whole-farm annual profits for pasture improvements ( US $\$ 65 /$ ha) and grain supplementation ( US\$91/ha) were consistent with other Brazilian studies for Nelore cattle. Whole-farm profits ranged from US $\$ 57$ to 91/ha for pasture improvements including re-seeding in Acre state in the Amazon [45]. Profits were US\$66.72/ha for pasture fertilization in Minas Gerais state in Brazil's Atlantic Forest biome [50]. Pasture-based grain supplementation (GS) economic analyses have previously been limited to two studies on temperate cattle finished on the productive, diversified temperate pastures in Brazil's southern Pampas biome. Pasturing on soybean residues increased farm profits to US $\$ 124 /$ ha compared to US\$81/ha for native pasture [51]. For Bos taurus in southern Brazil, profits for GS (US\$99/ha) was slightly lower compared to native pasture (US\$101/ha) [18].

\subsection{Reducing Carbon Footprint Using Pasture Improvements and Grain Supplementation}

For all simulated systems, our results are consistent with a study of Amazon Nelore, where pasture-based beef production system intensification can increase productive efficiency and mitigate certain environmental impacts [52]. The reduced carbon footprint $\left(\mathrm{kgCO}_{2} \mathrm{eq} / \mathrm{kg} \mathrm{BW}\right)$ for our pasture re-seeding simulations ( $\sim 6 \%$ less) was lower than other studies for Brazilian Nelore cattle $[14,43,53]$ which ranged from $19 \%$ to $61 \%$ less. However, our simulated pasture improvements had greater indirect emissions from land management and production of external resources compared to extensive due to livestock feed and fertilizer production and use. Emissions from fuels were also higher for pasture re-seeding and fertilization due to machinery use.

For Brachiaria brizantha, accumulated carbon footprint (CF) over time was higher for fertilized pasture compared to degraded pasture [42]. In our improved pasture scenarios, GHG emissions per hectare were greater than other systems. As farms increase herd size and produce more pounds of meat per year on the same amount of land, emissions per hectare increase while emissions per kilogram of meat produced tend to decrease. Therefore, increased productivity lowers $\mathrm{CF}\left(\mathrm{kg} \mathrm{CO}_{2} \mathrm{eq} / \mathrm{kg} \mathrm{BW}\right)$ for intensified versus extensive systems [16].

Our simulated reduction in CF for pasture fertilization was consistent with prior research [16,32]. Pasture fertilization reduces grazing time due to better forage availability. Forage degradation by rumen microbiota is enhanced by lower amounts of cellulose in young plants. Better pasture productivity maintains constant leaf cover and a favorable carbon/nitrogen equilibrium $[47,53]$. Further lowering CF by increasing percent of pasture area fertilized beyond $10 \%$ eventually runs into cost limitations. Profits are negative at roughly -US $\$ 45 /$ ha/year (data not shown) in both biomes if $100 \%$ of pasture is fertilized annually.

Our lower carbon footprint (CF) for grain supplementation (GS) was consistent with a study of Nelore in the Amazon where grain supplementation reduced greenhouse gas emissions per kilogram of meat compared to traditional systems [54]. Ruminants fed high-grain diets have lower methane 
emissions compared to diets with more forage fiber [55]. The $16 \%$ reduction in CF for our GS simulations was within the range of $11 \%$ to $45 \%$ for studies involving Nelore crosses [56] and Nelore pure bred cattle [14].

The sustainable agricultural intensification strategies we modeled lowering Brazil Nelore beef carbon footprint is significant since cattle production makes up 96\% of beef sector emissions [57]. While our IFSM simulations focus on such cattle production, they do not model greenhouse gas (GHG) emissions from the deforestation process itself, where burning releases $\mathrm{CO}_{2}$ and subsequent extensive pastures have more limited carbon sequestration potential [58]. For example, after annualizing over a 20-year period, carbon footprint of Brazilian beef solely raised on deforested land is $726 \mathrm{~kg} \mathrm{CO} 2 \mathrm{eq} / \mathrm{kg}$ of body weight [59], which is 40 times greater than the CF for the beef systems we modeled.

Brazil has recently relied on public policies to reduce deforestation [60]. The Brazilian Forest Code mandates legal forest reserves of $80 \%$ in the Amazon and $20 \%$ in the Cerrado of property owned in rural areas [61]. The National Climate Change Plan targets reducing deforestation in the Amazon and Cerrado, while the Agricultura de Baixa Emissão de Carbono (ABC) plan encourages low-carbon agricultural emissions [62]. There are also Brazilian government programs for degraded pasture recovery [63]. For other areas of Brazil's beef value chain, such as product marketing and distribution, system-wide modeling can be essential for determining systems with lower GHG emissions [64].

\subsection{Carbon Emissions, Water, Energy, and Nitrogen Impacts of Intensification}

Reducing Brazilian beef's carbon footprint is beneficial since Brazil is projected to increase beef production and exports [65] (USDA 2019). While it is important to determine which production systems can best lower GHG emissions per $\mathrm{kg}$ of beef produced, our results demonstrate that total GHG emissions per pasture area $\left(\mathrm{kg} \mathrm{CO}_{2} \mathrm{eq} / \mathrm{ha}\right)$ can more than double on existing pastures if stocking density is doubled from one to two head per hectare. So, while our simulations indicate pasture improvements and grain supplementation can reduce carbon footprint $(\mathrm{kg} \mathrm{CO} 2 \mathrm{eq} / \mathrm{kg}$ of beef body weight) by $\sim 5 \%$ to $\sim 16 \%$ compared to extensive pasture, this is less than CF reduction of almost $60 \%$ required for GHG emissions per hectare for the alternative systems we modeled to equal extensive pasture at half the stocking density. In the long run, reducing total GHG emissions by doubling Brazil's beef production on the same pasture area may be challenging. However, in the short run, annualized GHG emissions may be lowered by reducing age to slaughter from the Brazilian average of four years [66] to two years. IFSM currently limits age to slaughter at three years.

Reducing both current and future GHG emissions per area and per kg of beef produced in Brazil is critical due the contribution to such emissions from cattle. Enteric fermentation from microbial decomposition of food in the rumen releases methane $\left(\mathrm{CH}_{4}\right)$, which is the largest proportion of total GHG emissions in beef cattle production systems [32]. Beef and dairy cattle are estimated to contribute to $68 \%$ of total Brazilian $\mathrm{CH}_{4}$ emissions [67] and 56\% of total agricultural GHG emissions nationwide [68]. In addition to enteric fermentation from cattle, other GHG sources include manure storage and land application releasing $\mathrm{CH}_{4}$ and nitrous oxide $\left(\mathrm{N}_{2} \mathrm{O}\right)$, as well as $\mathrm{N}_{2} \mathrm{O}$ and $\mathrm{CO}_{2}$ from feed production [58].

Deforestation restrictions, especially in the Amazon biome, increasing agricultural land use and appreciation, and the need to control pasture degradation and greenhouse gas emissions have all contributed to producers reconsidering traditional extensive beef grazing [69]. Our results were consistent with the SimPec model of Mato Grosso state Nelore cattle which showed grain supplementation had more favorable reduction in CF compared to pasture restoration [70]. However, improving degraded pasture and grain supplementation may not be enough to reduce total and per hectare GHG emissions. Although producers have been slow to adopt integrated crop, livestock, forestry systems due to its management complexity [71,72], integrating commercial forestry (e.g., Eucalyptus spp.) can sequester $17,000 \mathrm{~kg} \mathrm{CO}_{2} \mathrm{eq} / \mathrm{ha} /$ year [42], which is $\sim 3.5$ times the emissions per hectare of the sustainable agricultural intensification systems we evaluated. 
Many low input, predominantly non-irrigated livestock systems have little impact on freshwater resources from consumable water use [73]. Due to the higher proportion of concentrate in the diet, the total water consumption per hectare and per $\mathrm{kg}$ of beef body weight by animals is higher for GS consistent with prior research [32,74]. Our simulated water use for pasture improvements was higher per $\mathrm{kg}$ of beef body weight (BW) compared to extensive, but was lower per hectare in the Cerrado $(-13 \%)$ and Amazon (-5\%) biomes (Supplementary Materials, Table S4). Thus, there appears to be greater responsiveness of reducing water use from improved pasture management for the more water limited Cerrado compared to the less water limited Amazon (Figure 2, Figures S1 and S2).

It is understandable that increased GHG emissions, nitrogen loss, and energy use per ha for our pasture re-seeding/fertilization and grain supplementation models were driven by doubling cattle stocking density. However, even though beef productivity more than doubled, both pasture re-seeding/fertilization and grain supplementation models had greater water footprint $(\mathrm{kg} / \mathrm{kg}$ cattle BW) and pasture re-seeding/fertilization has greater energy and nitrogen footprints compared to extensive pasture, underscoring the potential environmental impacts that such initial pasture-based intensification entails. If Brazil follows the U.S. beef intensification pathway toward more industrial feedlots, there could be increases in GHG's, nitrogen losses, and energy use per hectare, water footprint, and also negative external impacts to groundwater and watersheds [75], even though feedlots have been shown to reduce deforestation [76].

\section{Conclusions}

The Integrated Farm System Model software was used to model two cooperating beef farms, one in the Amazon and one in the Cerrado biome in Mato Grosso state, Brazil. The simulated dry matter consumption was consistent with grazing estimates and concentrated feed consumed by beef cattle on the two collaborating farms, demonstrating that the IFSM model can simulate tropical beef systems. When simulating sustainable agricultural intensification strategies, beef production and economic returns were greatest for grain supplementation of cattle followed by pasture re-seeding or pasture fertilization and lowest for extensive pasture. The three sustainable intensification strategies modeled had double the beef cattle stocking density compared to extensive grazing. This increased beef productivity which improved environmental footprints. Grain supplementation, pasture re-seeding, and pasture fertilization all had lower carbon footprint compared to extensive grazing. While grain supplementation had lower energy use and nitrogen loss, these were greater for both pasture management strategies. Water footprint was greater for all three intensification strategies compared to extensive grazing. While grain supplementation had the best beef productivity, economic profitability, and lowest carbon footprint of all simulated systems, intensifying pasture management in Brazil's Midwest could do better at reducing competition of livestock feed with human food.

Supplementary Materials: The following are available online at http://www.mdpi.com/2076-2615/10/8/1386/s1, Table S1: General costs, livestock expenses/year (US\$/head), commodity prices (US\$/metric ton of dry matter), cattle prices, useful life of capital (years), salvage value (\% of initial value), interest rate (\%) and fertilizer prices (US\$ $/ \mathrm{kg}$ ) for simulated systems in the Amazon and Cerrado biomes, Brazil, Table S2: Soil characteristics of the simulated systems for the Cerrado and Amazonia biomes, Brazil, Table S3: Annual average emissions of greenhouse gases (GHG) and natural resource use per farm simulated in IFSM for the extensive beef system, pasture seeding (PS), pasture fertilization (PF), and grain supplementation (GS) in the Cerrado and Amazon biomes, Brazil, Table S4: Annual average emissions of greenhouse gases (GHG) and natural resource use per hectare simulated in IFSM for the extensive beef system, pasture seeding (PS), pasture fertilization (PF), and grain supplementation (GS) in the Cerrado and Amazon biomes, Brazil, Figure S1: Precipitation at cooperating farm and Cuiabá weather stations (2015-2018) in the Cerrado biome, Figure S2: Precipitation at the cooperating farm weather station (2015-18) in the Amazon biome.

Author Contributions: Conceptualization, L.M., A.K.H., and L.M.P.; methodology, A.K.H. and D.C.d.A.; validation, L.M., A.K.H. and L.M.P.; formal analysis, L.M., A.K.H., and L.P.; investigation, L.M., L.M.P., D.C.d.A.; resources, D.C.A., A.S.d.O., A.K.H.; writing-original draft preparation, L.M., A.K.H., L.M.P., and D.C.d.A.; writing-review and editing, All authors; visualization, A.K.H. and D.C.d.A.; supervision, A.S.d.O., D.C.d.A., and A.K.H.; project administration, D.C.A. and A.S.d.O.; funding acquisition, D.C.d.A. and A.K.H. All authors have read and agreed to the published version of the manuscript. 
Funding: This research was financially supported by Fundação de Amparo à Pesquisa do Estado de Mato Grosso (FAPEMAT) for granting a masters scholarship (017/2015), Grupo Osvaldo Sobrinho, Instituto de Ciências Agrárias e Ambientais (ICAA), and Serviço Nacional de Aprendizagem Rural de Mato Grosso (SENAR-MT). This research was not funded by any internal nor external grants. The APC was funded by AgriSciences program at the Universidade Federal de Mato Grosso and the authors.

Acknowledgments: We first and foremost thank our cooperating farmers, especially Osvaldo Roberto Sobrinho, for allowing our research team to collect economic and agronomic data on sustainable agricultural intensification practices in addition to meteorological data over the three years of our study. Special thanks to the AgriSciences program at the Universidade Federal de Mato Grosso for resources supporting cooperating farm visits and to Ronaldo Alves de Oliveira for assistance creating the map of the study area. We are also grateful to "Interações Ambiente e Planta" research group at the Universidade Federal de Mato Grosso, for providing us with the historical meteorological data of the studied locations. We also thank the SENAR-MT and ICAA at the Universidade Federal de Mato Grosso, for the support and incentive for the publication of this study.

Conflicts of Interest: The authors declare no conflict of interest. The funders had no role in the design of the study; in the collection, analyses, or interpretation of data; in the writing of the manuscript, or in the decision to publish the results.

\section{References}

1. Chang, Y.; Li, G.; Yao, Y.; Zhang, L.; Yu, C. Quantifying the water-energy-food nexus: Current status and trends. Energies 2016, 9, 65. [CrossRef]

2. Food and Agriculture Organization (FAO). 2010. Available online: http://www.fao.org/fileadmin/templates/ wsfs/docs/expert_paper/How_to_Feed_the_World_in_2050.pdf (accessed on 19 September 2019).

3. Dias, L.C.P.; Pimenta, F.M.; Santos, A.B.; Costa, M.H.; Ladle, R.J. Patterns of land use, extensification, and intensification of Brazilian agriculture. Glob. Chang. Biol. 2016, 22, 2887-2903. [CrossRef] [PubMed]

4. Associação Brasileira das Indústrias Exportadoras de Carnes (ABIEC). Available online: http://abiec.siteoficial. ws/images/upload/sumario-pt-010217.pdf (accessed on 1 May 2019).

5. Batistella, M.; Andrade, R.G.; Bolfe, É.L.; Victoria, D.C.; Silva, G.B.S. Geotecnologias e gestão territorial da bovinocultura no Brasil. R. Bras. Zootec. 2011, 40, 251-260.

6. Embrapa. Embrapa Cerradoes. 2012. Available online: http://www.cpac.embrapa.br/unidade/apresentacao/ (accessed on 17 August 2019).

7. Instituto Brasileiro de Geografia e Estatística (IBGE). IBGE atualiza Mapa da Amazônia Legal. 2020. Available online: https:/agenciadenoticias.ibge.gov.br/agencia-sala-de-imprensa/2013-agencia-de-noticias/releases/ 28089-ibge-atualiza-mapa-da-amazonia-legal (accessed on 7 July 2020).

8. Barbosa, F.A.; Soares-Filho, B.S.; Merry, F.D.; Azevedo, H.O.; Costa, W.L.S.; Coe, M.T.; Batista, E.L.S.; Maciel, T.G.; Sheepers, L.C.; Oliveira, A.R.; et al. Cenários Para a Pecuária de Corte Amazônica; Universidade Federal de Minas Gerais: Belo Horizonte, Brazil, 2015; p. 154.

9. Joly, C.A.; Scarano, F.R.; Bustamante, M.; Gadda, T.M.C.; Metzger, J.P.W.; Seixas, C.S.; Ometto, J.P.H.B.; Pires, A.P.F.; Boesing, A.L.; Sousa, F.D.R.; et al. Brazilian assessment on biodiversity and ecosystem services: Summary for policy makers. Biota Neotrop. 2019, 19, e20190865. [CrossRef]

10. Intergovernmental Panel on Climate Change (IPCC). Refinement to the 2006 IPCC Guidelines for National Greenhouse Gas Inventories. 2019. Available online: https://www.ipcc.ch/report/2019-refinement-to-the2006-ipcc-guidelines-for-national-greenhouse-gas-inventories/ (accessed on 7 July 2020).

11. Silva, C.M. Entre Fênix e Ceres: A grande aceleração e a fronteira agrícola no Cerrado. Var. Hist. 2018, 34, 409-444. [CrossRef]

12. Bungenstab, D.J. Brazilian Beef Cattle: Reducing Global Warming by the Production Systems Efficiency; Documents/Embrapa Gado de Corte: Embrapa, Brasília, 2012; p. 38.

13. Dick, M.; Silva, M.A.; Dewes, H. Life cycle assessment of beef cattle production in two typical grassland systems of Southern Brazil. J. Clean. Prod. 2015, 96, 426-434. [CrossRef]

14. Cardoso, A.S.; Berndt, A.; Leytem, A.; Alves, B.J.R.; Carvalho, I.N.O.; Soares, L.H.B.; Urquiaga, S.; Boddey, R.M. Impact of the intensification of beef production in Brazil on greenhouse gas emissions and land use. Agric. Syst. 2016, 143, 86-96. [CrossRef]

15. Latawiec, A.E.; Strassburg, B.B.N.; Valentim, J.F.; Ramos, F.; Alves-Pinto, H.N. Intensification of cattle ranching production systems: Socioeconomic and environmental synergies and risks in Brazil. Animal 2014, 8, 1255-1263. [CrossRef] 
16. Bogaerts, M.; Cirhigiri, L.; Robinson, I.; Rodkin, M.; Hajjar, R.; Costa Junior, C.; Newton, P. Climate change mitigation through intensified pasture management: Estimating greenhouse gas emissions on cattle farms in the Brazilian Amazon. J. Clean. Prod. 2017, 162, 1539-1550. [CrossRef]

17. Rocha, T.C.; Fontes, C.A.A.; Silva, R.T.S.; Processi, E.F.; Valle, F.R.A.F.; Lombardi, C.T.; Oliveira, R.L.; Bezerra, L.R. Performance, nitrogen balance and microbial efficiency of beef cattle under concentrate supplementation strategies in intensive management of a tropical pasture. Trop. Anim. Health Prod. 2016, 48, 673-681. [CrossRef]

18. Pereira, C.H.; Patino, H.O.; Hoshide, A.K.; Abreu, D.C.; Alan Rotz, C.; Nabinger, C. Grazing supplementation and crop diversification benefits for southern Brazil beef: A case study. Agric. Syst. 2018, 162, 1-9. [CrossRef]

19. Rotz, C.A.; Veith, T.L. Integration of air and water quality issues. In Sustainable Animal Agriculture; Kebreab, E., Ed.; CABI: Oxfordshire, UK, 2013; Chapter 10; p. 336, ISBN 9781780640426.

20. Rotz, C.A.; Corson, M.S.; Chianese, D.S.; Montes, F.; Hafner, S.D.; Bonifacio, H.F.; Coiner, C.U. The Integrated farm system model 4.4. United States Department of Agriculture (USDA). Pasture Systems and Watershed Management Research Unit. Agric. Res. Serv. 2018, 250,1-191.

21. Rotz, C.A.; Stackhouse, K.R. Comprehensive national assessment on the sustainability of beef production. J. Anim. Sci. 2016, 94, 328. [CrossRef]

22. Dutreuil, M.; Wattiaux, M.; Hardie, C.A.; Cabrera, V.E. Feeding strategies and manure management for cost-effective mitigation of greenhouse gas emissions from dairy farms in Wisconsin. J. Dairy Sci. 2014, 97, 5904-5917. [CrossRef]

23. Corson, M.S.; Rotz, C.A.; Skinner, R.H.; Sanderson, M.A. Adaptation and evaluation of the integrated farm system model to simulate temperate multiple-species pastures. Agric. Syst. 2007, 94, 502-508. [CrossRef]

24. Rotz, C.A.; Mertens, D.R.; Buckmaster, D.R.; Allen, M.S.; Harrison, J.H. A dairy herd model for use in whole farm simulations. J. Dairy Sci. 1999, 82, 2826-2840. [CrossRef]

25. Rotz, C.A.; Kamphuis, G.H.; Karsten, H.D.; Weaver, R.D. Organic dairy production systems in Pennsylvania: A case study evaluation. J. Dairy Sci. 2007, 90, 3961-3979. [CrossRef]

26. Belflower, J.B.; Bernard, J.K.; Gattie, D.K.; Hancock, D.W.; Risse, L.M.; Rotz, C.A. A case study of the potential environmental impacts of different dairy production systems in Georgia. Agric. Syst. 2012, 108, 84-93. [CrossRef]

27. Gil, J.; Garrett, R.D.; Rotz, A.; Daioglou, V.; Valentim, J.; Pires, G.F.; Costa, M.H.; Lopes, L.; Reis, J.C. Tradeoffs in the quest for climate smart agricultural intensification in Mato Grosso, Brazil. Environ. Res. Lett. 2018, 13, 064025. [CrossRef]

28. Bowman, M.S.; Soares-Filho, B.S.; Merry, F.D.; Nepstad, D.C.; Rodrigues, H.; Almeida, O.T. Persistence of cattle ranching in the Brazilian Amazon: A spatial analysis of the rationale for beef production. Land Use Policy 2012, 29, 558-568. [CrossRef]

29. Martha, G.B., Jr.; Alves, E.; Contini, E. Land-saving approaches and beef production growth in Brazil. Agric. Syst. 2012, 110, 173-177. [CrossRef]

30. National Research Council (NRC). Nutrient Requirements of Beef Cattle, 8th ed.; National Academies Press: Washington, DC, USA, 2016; p. 494, ISBN 978-0-309-31702-3. [CrossRef]

31. CQBAL 4.0. Tabelas Brasileiras de Composição de Alimentos para Ruminantes. Available online: http: //www.cqbal.com.br/\#!/ (accessed on 26 March 2020).

32. Mazzetto, A.M.; Feigl, B.J.; Schils, R.L.M.; Cerri, C.E.P.; Cerri, C.C. Improved pasture and herd management to reduce greenhouse gas e missions from a Brazilian beef production system. Livest. Sci. 2015, 175, 101-112. [CrossRef]

33. Restle, J.R.; Vaz, F.N.; Roso, C.; de Oliveira, A.N.; Cerdótes, L.; de Menezes, L.F.G. Desempenho e características da carcaça de cacas de diferentes grupos genéticos em pastagem cultivada com suplementação energética. Rev. Bras. Zootec. 2001, 30, 1813-1823. [CrossRef]

34. Ertl, P.; Klocker, H.; Hörtenhuber, S.; Knaus, W.; Zollitsch, W. The net contribution of dairy production to human food supply: The case of Austrian dairy farms. Agric. Syst. 2015, 137, 119-125. [CrossRef]

35. Sá, J.M.; Urquiaga, S.; Jantalia, C.P.; Soares, L.H.B.; Alves, B.J.R.; Boddey, R.M.; Marchão, R.L.; Vilela, L. Balanço energético da produção de grãos, carne e biocombustíveis em sistemas especializados e mistos. Pesq. Agropec. Bras. 2013, 48, 1323-1331. [CrossRef] 
36. Pedrosa, L.M.; Hoshide, A.K.; Abreu, D.C.; de Molossi, L.; Couto, E.G. Financial transition and costs of sustainable agricultural intensification practices on a beef cattle and crop farm in Brazil's Amazon. Renew. Agric. Food Sys. 2019, 1-12. [CrossRef]

37. Rotz, C.A.; Oenema, J.; van Keulen, H. Whole farm management to reduce nutrient losses from dairy farms: A simulation study. Appl. Eng. Agric. 2006, 22, 773-784. [CrossRef]

38. Food and Agriculture Organization (FAO). OECD-FAO Agricultural Outlook 2019-2028. 2019. Available online: http://www.fao.org/3/ca4076en/ca4076en.pdf (accessed on 21 July 2020).

39. Meirelles Filho, J.C.S. Is it possible to overcome the legacy of the Brazilian dictatorship (1964-1985) and keep deforestation in the Amazon under control? Not as long as cattle ranching continues as the main cause of deforestation. Cienc. Hum. 2014, 9, 219-241.

40. Strassburg, B.B.N.; Latawiec, A.E.L.; Barioni, L.G.; Nobre, C.A.; Silva, V.P.; Valentim, J.F.; Vianna, M.; Assad, E.D. When enough should be enough: Improving the use of current agricultural lands could meet production demands and spare natural habitats in Brazil. Glob. Environ. Chang. 2014, 28, 84-97. [CrossRef]

41. Landers, J.N. Food and Agriculture Organization of the United Nations. In Tropical Crop-Livestock Systems in Conservation Agriculture: The Brazilian Experience; Integrated Crop Management: Rome, Italy, 2007; Volume 5, p. 92, ISBN 978-92-5-105692-9.

42. Figueiredo, E.B.; Jayasundara, S.; Bordonal, R.O.; Berchielli, T.T.; Reis, R.A.; Wagner-Riddle, C.; La Scala, N. Greenhouse gas balance and carbon footprint of beef cattle in three contrasting pasture-management systems in Brazil. J. Clean. Prod. 2017, 142, 420-431. [CrossRef]

43. De Oliveira Silva, R.; Barioni, L.G.; Hall, J.A.J.; Moretti, A.C.; Fonseca Veloso, R.; Alexander, P.; Crespolini, M.; Moran, D. Sustainable intensification of Brazilian livestock production through optimized pasture restoration. Agric. Syst. 2017, 153, 201-211. [CrossRef]

44. Garcia, E.; Filho, F.S.V.R.; Mallmann, G.M.; Fonseca, F. Costs, benefits and challenges of sustainable livestock intensification in a major deforestation frontier in the Brazilian amazon. Sustainability 2017, 9, 158. [CrossRef]

45. Zu Ermgassen, E.K.H.J.; de Alc\#xE2;ntara, M.P.; Balmford, A.; Barioni, L.; Neto, F.B.; Bettarello, M.M.F.; de Brito, G.; Carrero, G.C.; Florence, E.d.A.S.; Garcia, E.; et al. Results from on-the-ground efforts to promote sustainable cattle ranching in the Brazilian Amazon. Sustainability 2018, 10, 1301. [CrossRef]

46. Oliveira, P.P.A.; Corte, R.R.S.; Silva, S.L.; Rodriguez, P.H.M.; Sakamoto, L.S.; Pedroso, A.F.; Tullio, R.R.; Berndt, A. The effect of grazing system intensification on the growth and meat quality of beef cattle in the Brazilian Atlantic Forest biome. Meat Sci. 2018, 139, 157-161. [CrossRef]

47. Santos, R.S.M.; Oliveira, I.P.; Morais, R.F.; Urquiaga, S.C.; Boddey, R.M.; Alves, B.J.R. Componentes da parte aérea e raízes de pastagens de Brachiaria spp. em diferentes idades após a reforma, como indicadores de produtividade em ambiente de cerrado. Pesq. Agropec. Trop. 2007, 37, 119-124.

48. Moraes, E.H.B.K.; Paulino, M.F.; Valadares Filho, S.C.; Moraes, K.A.K.; Detmann, E.; Gonçalves, M. Nutritional evaluation of supplementation strategies for beef cattle during the dry season. Rev. Bras. Zootec. 2010, 39, 608-616. [CrossRef]

49. Baber, J.R.; Sawyer, J.E.; Wickersham, T.A. Estimation of human-edible protein conversion efficiency, net protein contribution, and enteric methane production from beef production in the United States. Transl. Anim. Sci. 2018, 2, 439-450. [CrossRef]

50. Santana, R.A.V.; Barbosa, F.A.; Andrade, V.J.; de Molina, P.C.; Filho, G.H.B.M.; Leão, J.M. Risk analysis and probability of return on invested capital in an intensive beef cattle production system in Minas Gerais, Brazil. Rev. Brasil. Zootec. 2016, 45, 788-793. [CrossRef]

51. Pashaei Kamali, F.; van der Linden, A.; Meuwissen, M.P.M.; Malafaia, G.C.; Oude Lansink, A.G.J.M.; de Boer, I.J.M. Environmental and economic performance of beef farming systems with different feeding strategies in southern Brazil. Agric. Syst. 2016, 146, 70-79. [CrossRef]

52. Cortner, O.; Garret, R.D.; Valentim, J.F.; Ferreira, J.; Niles, M.T.; Reis, J.; Gil, J. Perceptions of integrated crop-livestock systems for sustainable intensification in the Brazilian Amazon. Land Use Policy 2019, 82, 841-853. [CrossRef]

53. Johnson, C.R.; Reiling, B.A.; Mislevy, P.; Hall, M.B. Effects of nitrogen fertilization and harvest date on yield, digestibility, fiber, and protein fractions of tropical grasses. J. Anim. Sci. 2001, 79, 2439-2448. [CrossRef] [PubMed]

54. Swain, M.; Blomqvist, L.; McNamara, J.; Ripple, W.J. Reducing the environmental impact of global diets. Sci. Tot. Environ. 2018, 610, 1207-1209. [CrossRef] 
55. Oliveira, E.R.; Monção, F.P.; Góes, R.H.T.B.; Gabriel, A.M.A.; Paz, I.C.L.A.; Nääs, I.A.; Santos, R.C.; Moura, L.V. Bioprodutos do cerrado: Alternativas alimentares na redução da emissão de metano em bovinos-estudo de caso. Rev. Agrarian. 2014, 7, 369-381.

56. Florindo, T.J.; Florindo, G.I.B.M.; Talamini, E.; Costa, J.S.; da Riviaro, C.F. Carbon footprint and life cycle costing of beef cattle in the Brazilian Midwest. J. Clean. Prod. 2017, 147, 119-129. [CrossRef]

57. Florindo, T.J.; de Florindo, G.I.B.M.; Talamini, E.; da Costa, J.S.; de Léis, C.M.; Tang, W.Z.; Schultz, G.; Kulay, L.; Pinto, A.T.; Ruviaro, C.F. Application of the multiple criteria decision-making (MCDM) approach in the identification of Carbon Footprint reduction actions in the Brazilian beef production chain. J. Clean. Prod. 2018, 196, 1379-1389. [CrossRef]

58. Desjardins, R.L.; Worth, D.E.; Vergé, X.P.C.; Maxime, D.; Dyer, J.; Cerkowniak, D. Carbon footprint of beef cattle. Sustainability 2012, 4, 3279-3301. [CrossRef]

59. Cedeberg, C.; Persson, U.M.; Neovius, K.; Molander, S.; Clift, R. Including carbon emissions from deforestation in the carbon footprint of Brazilian beef. Environ. Sci. Technol. 2011, 45, 1773-1779. [CrossRef]

60. Costa, N.B.C., Jr.; Baldissera, T.C.; Pinto, C.E.; Garagorry, F.C.; Moraes, A.; Carvalho, P.C.F. Public policies for low carbon emission agriculture foster beef cattle production in southern Brazil. Land Use Policy 2019, 80, 269-273. [CrossRef]

61. Spera, S.A.; Galford, G.L.; COE, M.T.; Macedo, M.N.; Mustard, J.F. Land-use change affects water recycling in Brazil's last agricultural frontier. Glob. Chang. Biol. 2016, 22, 3405-3413. [CrossRef]

62. Kimura, W.J.; Santos, E.F. Custo marginal de abatimento de emissões de gases de efeito estufa na recuperação da pastagem. Rev. Pecege 2016, 2, 9-23. [CrossRef]

63. Lobato, J.F.P.; Freitas, A.K.; Devincenzi, T.; Cardoso, L.L.; Tarouco, J.U.; Vieira, R.M.; Dillenburg, D.R.; Castro, I. Brazilian beef produced on pastures: Sustainable and healthy. Meat Sci. 2014, 98, 336-345. [CrossRef] [PubMed]

64. Cottle, D.J.; Nolan, J.V.; Wiedemann, S.G. Ruminant enteric methane mitigation: A review. Anim. Prod. Sci. 2011, 51, 491-514. [CrossRef]

65. United States Department of Agriculture (USDA). Brazil: Livestock and Products Annual. 2019. Available online: https://apps.fas.usda.gov/newgainapi/api/report/downloadreportbyfilename?filename=Livestock $\%$ 20and\%20Products\%20Annual_Brasilia_Brazil_9-5-2019.pdf (accessed on 8 April 2020).

66. Ferraz, J.B.S.; de Felício, P.E. Production systems-An example from Brazil. Meat Sci. 2010, 84, $238-243$. [CrossRef] [PubMed]

67. Berchielli, T.T.; Messana, J.D.; Canesin, R.C. Produção de metano entérico em pastagens tropicais. Rev. Bras. Saúde Prod. Anim. 2012, 13, 954-968. [CrossRef]

68. Oliveira, P.P.A. Gases de efeito estufa em sistemas de produção animal brasileiros e a importância do balanço de carbono para a preservação ambiental. Rev. Bras. Geo. Física 2015, 08, 623-634. [CrossRef]

69. Barioni, L.G.; Ferreira, A.C. Monitormaneto da massa de forragem e altura para ajustes de taxa de lotação em fazenda agropecuária na região do cerrado. In Boletim de Pesquisa e Desenvolvimento; Embrapa: Cerrados, Planaltina/DF, Brazil, 2007; Volume 191, pp. 1-24.

70. Batista, E.; Soares-Filho, B.; Barbosa, F.; Merry, F.; Davis, J.; van der Hoff, R.; Rajão, R.G. Large-scale pasture restoration may not be the best option to reduce greenhouse gas emissions in Brazil. Environ. Res. Lett. 2019, 14, 125009. [CrossRef]

71. Gil, J.; Siebold, M.; Berger, T. Adoption and development of integrated crop-livestock-forestry systems in Mato Grosso, Brazil. Agric. Ecosyst. Environ. 2015, 199, 394-406. [CrossRef]

72. Alves, B.J.R.; Madari, B.E.; Boddey, R.M. Integrated crop-livestock-forestry systems: Prospects for a sustainable agricultural intensification. Nurt. Cycl. Agroecosyst. 2017, 108, 1-4. [CrossRef]

73. Ridoutt, B.G.; Sanguansri, P.; Freer, M.; Harper, G.S. Water footprint of livestock: Comparison of six geographically defined beef production systems. Int. J. Life Cycle Assess. 2012, 17, 165-175. [CrossRef]

74. Bonadimann, R.; Moraes, E.H.B.K.; Moraes, K.A.K.; Pina, D.S.; Oliveira, A.S.; Meneses, D.M.; Stinguel, H.; Almeida, C.M. Frequency of concentrate supplementation for grazing beef cattle. Semin. Ciênc. Agrár. Londr. 2017, 38, 2141-2150. [CrossRef] 
75. Merry, F.; Soares-Filho, B. Will intensification of beef production deliver conservation outcomes in the Brazilian Amazon? Elem. Sci. Anthr. 2017, 5, 24. [CrossRef]

76. Vale, P.; Gibbs, H.; Vale, R.; Christie, M.; Florence, E.; Munger, J.; Sabaini, D. The expansion of intensive beef farming to the Brazilian Amazon. Glob. Environ. Chang. 2019, 57, 101922. [CrossRef]

(C) 2020 by the authors. Licensee MDPI, Basel, Switzerland. This article is an open access article distributed under the terms and conditions of the Creative Commons Attribution (CC BY) license (http://creativecommons.org/licenses/by/4.0/). 